\title{
The effect of plumage modifier genes on egg quality indices of the Nigerian local chicken
}

\author{
J.O. Egahi*, N.I. Dim and O.M. Momoh \\ Department of Animal Breeding and Physiology University of Agriculture
}

\begin{abstract}
The effect of plumage modifier genes on some internal and external egg quality indices in the Nigerian local chicken in the guinea savanna was evaluated. The frizzle (ff) and naked neck (Na) local birds had a significantly $(p<0.05)$ higher egg weight than the normal feathered birds $(n a)$. Mean egg weights were 33.29 $0.27,36.160 .20$ and 43.150 .21 in the na, ff and $\mathrm{Na}$ genetic groups respectively. The frizzle and naked neck genes positively increased egg weights by 8.62 and 29.62 per cent over the normal feather gene. However, egg shape index significantly $(p<0.05)$ favoured the normal feathered birds over the other two genetic groups of the Nigerian local chicken studied. Similarly, shell thickness was significantly $(p<0.05)$ higher in the ff and Na birds than in the na. Consequently, the modifier genes of frizzling and naked neck are relevant in the development of a layer breed for the local environment.
\end{abstract}

\section{Introduction:}

The Nigerian local chicken exhibits diversity in morphological characteristics. Egahi et al. (2010) reported that they show heterogeneity in phenotypic characteristics. Badubi et al. (2006) observed that the diversity in form include plumage type, plumage colour, leg feathering and comb type. Peters et al. (2007) reported the presence of some major genes affecting feather structure and feather distribution in the Nigerian local chicken. Peters et al., (2007) further noted that the major genes of frizzling and naked neck are important as they enhance the thermoregulatory activities of the birds. Ibe (1990) reported that the naked neck and frizzling genes have indirect effects on quantitative trait loci (QTL). Several other researchers (Ikeobi et al., 1996; Peters et al. 2002 and Mathur 2003) have reported on the effects of the frizzle and naked genes on growth rate, egg number, fertility and hatchability in the Nigerian local chicken. Egg quality in chicken is influenced by several factors, which may be genetic or environmental (Peters et al., 2007). The current study was undertaken to investigate the effect of genetic factors influencing plumage (frizzle and naked neck) on egg quality indices of the Nigerian local chicken.

\section{Materials and methods:}

The study was carried out in Makurdi-Nigeria. The coordinates, rainfall pattern, humidity and temperature variations in Makurdi have been described by Dzungwe, (1991). The experimental birds were made up of 30 each of normal feathered (na), frizzle (ff) and naked neck (Na) genetic groups assembled from various markets within Makurdi and its environs. Each genetic group was maintained independent of the others on deep litter. All the genetic groups had ad libitum access to farm compounded layers' mash containing 16.5 percent crude protein and $2600 \mathrm{kcal} / \mathrm{kg}$ metabolizable energy. The birds were identified by wing tagging using coloured bias. Egss were identified according to the genetic groups and sire lines. Collected eggs were weighed immediately after collection using an electronic top loading balance with a sensitivity of $0.01 \mathrm{~g}$. Egg length and width were measured using a veneer caliper.

Egg shape index was calculated as described by Reddy et al. (1979).

Shape index $=($ egg width/egg length $) \times 100$

The internal egg quality indices were evaluated within 48 hours post oviposition. The parameters measured were:

Albumen height: - This was measured using the Veneer caliper.

Yolk height: - This was measured using the Vermeer caliper.

Yolk width: - This was measured around the widest horizontal circumference using the veneer caliper.

Shell thickness: - Shell thinness was measured as described by Chowdhurry (1987) using a micrometer screw guage.

Shell weight: - Shell weight was taken after allowing the empty egg shells to dry for 48 hours after cracking. The shell was placed on a digital sensitive electronic scale with $0.01 \mathrm{~g}$ sensitivity.

Haugh unit: - Individual Haugh unit (Haugh 1937) score was calculated using the egg weight and albumen height (Doyon et al., 1986). The Haugh unit values were calculated for individual egg using the following formula: 
$\mathrm{HU}=100 \log \left(\mathrm{H}-1.7 \mathrm{w}^{0.37}+7.6\right)$

Where:

$\mathrm{HU}=$ Haugh unit

$\mathrm{H}=$ Observed height of the albumen in $\mathrm{mm}$

$\mathrm{W}=$ Weight of egg $(\mathrm{g})$.

The model used for comparison among the genetic groups for egg quality indices was.

$Y_{i j}=\mu+a_{i}+e_{i j}$

Where

$\mathrm{Y}_{\mathrm{ij}}=$ Single observation

$\mu=$ Overall population mean .

$\mathrm{a}_{\mathrm{i}}=$ Effect of the $\mathrm{i}^{\text {th }}$ genetic group.

$\mathrm{e}_{\mathrm{ij}}=$ Residual random error.

\section{Results and Discussion}

Table 1 presents the least square means and standard errors for the external egg quality traits observed in the genetic groups. The external egg quality traits varied significantly $(\mathrm{p}<0.05)$ between the genetic groups of the Nigerian local chicken studied. Egg weight in the genetic groups ranged from $32.29 \pm 0.27$ to $43.15 \pm 0.23 \mathrm{~g}$. The frizzle and naked neck birds laid heavier eggs than the normal feathered birds genetic group. The observation in the current study was corroborated by earlier reports of Katuley (1990) that different genetic groups of fowls laid eggs of different sizes. Peters et al. (2007) similarly reported higher egg weights in the frizzle and naked neck Nigerian local chicken than the fully feathered birds. They observed that the major genes of frizzling and naked neck increased egg size by 8.13 and 5.85 per cent respectively. The current study observed an increase in egg size of 8.62 and 29.62 per cent respectively in the frizzle and naked neck genetic groups over the normal feathered birds. The 8.62 per cent increase in egg size in the frizzle birds over the normal feathered birds is similar to the 8.13 per cent increase reported by Peters et al. (2007) for the same genetic group in Abeokuta. However, the 29.62 per cent increase in the egg size of the naked neck birds over that of the normal feathered is much higher than the value of 5.86 per cent reported by Peters et al. (2007) in Abeokuta Nigeria. These reports are consistent with earlier reports by Horst (1988) and Ibe (1992) that the naked neck and frizzle chickens demonstrate superiority for egg number and egg weight over the fully feathered birds. Yalcin et al (1997) accounted that the observed variation may be due to the inherent ability of the naked neck birds to cope with stressful environmental conditions at high ambient temperatures above $30^{\circ} \mathrm{C}$ (which was characteristic of the current study environment). Similarly, Merat (1990) reported that the frizzling gene caused an increase in egg number and egg mass alongside reducing mortality. Thus, the major genes of frizzling and naked neck are important as they enhance the thermoregulatory activities of the birds (Peters et al. (2007).

Egg length and egg width varied significantly $(\mathrm{p}<0.05)$ between the genetic groups. The variation in egg length followed the same pattern with that of egg weight where the length of the naked neck and frizzle genetic groups were significantly $(\mathrm{p}<0.050$ higher than that of the normal feathered genotype. This observation is in agreement with the work of Monira et al. (2003) who reported significant variation among breeds of poultry for egg length.

The significant $(\mathrm{p}<0.05)$ difference between the groups for egg width is in agreement with the earlier reports by Katule (1990) and Peters et al. (2007).

Egg shape index varied significantly $(\mathrm{p}<0.05)$ between the genetic groups. The current study observed that egg shape index decreased with increase in egg weight. This is consistent with the report of Reddy et al (1979) and Monira et al. (2003). The egg shape index in the current study showed that the eggs of the normal feathered birds are more suitable to be packed in specialized containers for transportation.

There was significant $(p<0.05)$ variation between the genetic groups for all the internal egg quality parameters evaluated in this study. Yolk length varied from $16.01 \pm 0.18 \mathrm{~mm}$ in the normal feathered genetic group to $19.45 \pm 1.09 \mathrm{~mm}$ in the naked neck genetic group. Consequently, the naked neck birds had a significantly $(\mathrm{p}<0.05)$ higher yolk length than that of the other two genetic groups.

Albumen height ranged from $4.64 \pm 0.61$ in the normal feathered to $6.04 \pm 0.58$ in the frizzle birds. There was no significant ( $>0.05)$ difference between the frizzle and naked neck genetic groups for albumen height. Both genetic groups were however significantly different from the normal feathered genetic group. Monira et al. (2003) similarly reported that breed had a significant effect on albumen height. It can be inferred from the current study that the frizzle and naked neck genetic groups had better quality of egg albumen than the normal feathering genetic group.

Shell thickness ranged from $0.32 \pm 0.01$ to $0.36 \pm 0.01$ in the normal feathering and frizzle genetic groups respectively. The frizzle genotype had a significantly $(\mathrm{p}<0.05)$ higher shell weight than the other two genetic groups. Monira et al. (2003) similarly reported a significant $(\mathrm{p}<0.05)$ difference in shell weight between four layer breeds in Bangladesh. 
There was a significant $(\mathrm{p}<0.05)$ variation between the genetic groups for Haugh unit in the current study. This is in agreement with the report of Monira et al. (2003) that Haugh unit varied significantly between genetic groups of layer birds. Similarly, Peters et al. (2007) reported significant variation in Haugh unit for the same genetic groups of the Nigerian local chicken reported in this study.

Thus, the plumage modifier genes of frizzling and naked neck translate into superior performance in egg quality indices of birds possessing them. This is suggestive that these genes can be incorporated by poultry breeders in the development of local layer breeds in the current study environment.

\section{References}

[1] Badubi, S.S., Rakereng, M. and Marumo, M., (2006): Morphological characteristics and feed resources available for indigenous chickens in Botswana. Livest. Res. Rural Dev. 18(1),

[2] Dzungwe, T.A. (1991). The search for a viable Benue State. Benue State Gazette. pp.13-13.

[3] Egahi, J.O; N.I. Dim, O.M. Momoh and D.S. Gwaza (2010). Variations in Qualitative Traits in the Nigerian Local Chicken. International Journal of Poultry Science 9 (10): 978-979, 2010

[4] Ikeobi, C.O.N., Ebozoje, M.O., Adebambo, O.A.,Adenowo, J.A. and Osinowo, O.A. (1996). Genetic differences in the performance of the local chicken in South Western Nigeria. Nig. J. Genet., 11. pp55-60.

[5] Katuley A M (1990). Studies on the prospects of improving the performance of local chicken populations in Tanzania by cross breeding. Unpublished Thesis for Award of PhD Degree at Sokoine University of Agriculture.

[6] Mathur, P.K. (2003). genotypes-environment interactions: Problems associated with selection for increased production. In Muir W.M. and Aggrey, S.E (Eds). Poultry. Genetics, Breeding and Biotechnology, CABI Publishing 2003.

[7] Merat, P. (1990). Pleitropic and associated effects of major genes. In: Poultry Breeding and genetics, R.D Crawford, Ed. Elsevier Science publishers, the Netherlands. pp.429-468

[8] Monira K. N., Salahuddin M. and Miah G. (2003). Effect of Breed and holding Period on Egg Quality characteristics of Chicken. International Journal of Poultry Science 2 (4). pp. 261-263.

[9] Peters, S.O., Ikeobi, C.O.N., Ozoje, M.O., Famakinwa, O.A., Oshodi, Y.S. and Olufumilayo, A.A. (2007). Egg quality of the Nigerian local chicken as influenced by some major genes. Nig. J. Anim. Prod. 2007, 34(1). pp.25-31

[10] Reddy P.M; V.R. Reddy, C.V. Reddy and P.S.P Rap (1979). Egg weight, shape index and hatchability in Khaki, Campbell duck egg. Ind.J. Poult.Sc. 14. pp.26:31

[11] Smith, A.J. (1990). The Tropical Agriculturist: Poultry. The Macmillan Press Ltd, London. 218ppYalcin S., Testik A., Ozkan, S., Settar P., Celen F. and Cahaner A., (1997). Performance

[12] Yalcin S., Testik A., Ozkan, S., Settar P., Celen F. and Cahaner A., (1997). Performance of naked neck and normal broilers in hot, warm, and temperate climates. Poultry-sci.Savoy, IL: Poultry Science Association, Inc. Jul 1997. v. 76 (7) pp. $930-937$.

Table 1: Least Square Means Of External Egg Characteristics In The Genetic Groups of the Nigerian Local Chicken.

\begin{tabular}{lllll}
\hline Genetic Group & Egg Weight $(\mathrm{g})$ & Egg Length $(\mathrm{mm})$ & Egg Width $(\mathrm{mm})$ & Shape Index $(\%)$ \\
\hline NF x NF & $33.29 \pm 0.27^{\mathrm{c}}$ & $35.90 \pm 0.09^{\mathrm{c}}$ & $27.28 \pm 0.06^{\mathrm{b}}$ & $76.99^{\mathrm{a}}$ \\
$\mathrm{FF} \times \mathrm{FF}$ & $36.16 \pm 0.02^{\mathrm{b}}$ & $39.21 \pm 0.02^{\mathrm{b}}$ & $27.91 \pm 0.05^{\mathrm{b}}$ & $71.18^{\mathrm{b}}$ \\
$\mathrm{Na} \times \mathrm{Na}$ & $43.15 \pm 0.23^{\mathrm{a}}$ & $46.54 \pm 0.12^{\mathrm{a}}$ & $32.34 \pm 0.07^{\mathrm{a}}$ & $69.49^{\mathrm{c}}$ \\
\hline
\end{tabular}

Means with different superscript down the group (vertically) are significantly different at $\mathrm{P}<0.05$.

NF-Normal feathered genotype. $\quad$ FF- Frizzle feathered genotype. Na- Naked neck genotype

Table 2: Least Mean Squares of Internal Egg Characteristics In The Genetic Groups of the Nigerian Local Chicken.

\begin{tabular}{lllcccc}
\hline $\begin{array}{l}\text { Genotypic } \\
\text { Group }\end{array}$ & $\begin{array}{l}\text { Yolk Length } \\
(\mathrm{mm})\end{array}$ & $\begin{array}{l}\text { Albumen } \\
(\mathrm{mm})\end{array}$ & $\begin{array}{r}\text { Height } \\
\text { NF x NF }\end{array}$ & $\begin{array}{l}\text { Shell weight } \\
(\mathrm{g})\end{array}$ & $\begin{array}{r}\text { Shell thickness } \\
(\mathrm{mm})\end{array}$ & $\begin{array}{r}\text { Haugh Unit } \\
\text { FF x FF }\end{array}$ \\
$16.01 \pm 0.18^{\mathrm{b}}$ & $4.64 \pm 0.61^{\mathrm{b}}$ & $6.39 \pm 0.01^{\mathrm{c}}$ & $0.32 \pm 0.01^{\mathrm{c}}$ & $96.28^{\mathrm{a}}$ \\
$\mathrm{Na} \times \mathrm{Na}$ & $19.45 \pm 1.09^{\mathrm{a}}$ & $5.04 \pm 0.58^{\mathrm{a}}$ & $7.02+0.01^{\mathrm{b}}$ & $0.36 \pm 0.01^{\mathrm{a}}$ & $90.16^{\mathrm{c}}$ \\
\hline
\end{tabular}

Values with different superscripts down the group (verically) are significantly different at $\mathrm{P}<0.05$.

NF-Normal feathered genotype. FF- Frizzle feathered genotype. Na- Naked neck genotype 